Article

\title{
Living as Residents in a Tourist Destination: A Phenomenological Approach
}

\author{
Jee-Eun Lim ${ }^{1}$ and Hyung Ryong Lee ${ }^{2, *}$ \\ 1 Institute of Tourism Industry, Sejong University, Seoul 05006, Korea; jelim@sejong.ac.kr \\ 2 Department of Hospitality and Tourism Management, Sejong University, Seoul 05006, Korea \\ * Correspondence: hrlee@sejong.ac.kr
}

Received: 31 December 2019; Accepted: 18 February 2020; Published: 29 February 2020

\begin{abstract}
Many people have lived in tourist destinations even before such areas became well known, and will continue to live in these areas whether tourism is successful or not. This study explores residents' subjective thoughts and perspectives by using a phenomenological methodology. Phenomenology is a theory that seek to understand an individual's recognition of their own subjectivity rather than explaining objective factors about an individual. We collected data from interviews with 13 residents of Bulguk-dong Gyeongju City, which has long experienced the ups and downs of being a tourist destination. The phenomenological results were expressed as three themes: (1) Being a resident with an inevitable choice, (2) the meaning of tourism in the lived experience as a resident, (3) the formation of conflicts. In conclusion, the lived experience of the residents at the tourist destination is considered "a route for individuals to protect themselves within an ever-changing social structure". From this perspective, the tourism industry must have multilateral and detailed information about residents, and not just assume that the residents have either a positive or negative attitude towards tourism development.
\end{abstract}

Keywords: sustainability; sustainable tourism; tourist destination; residents; phenomenological approach

\section{Introduction}

Residents are the most crucial topic in destination sustainability issues as residents are an essential element needed to maintain a destination. The same is true for tourist attractions. Many parts of the world seek tourism benefits in order to maintain residents' livelihoods as traditional industries collapse [1]. These residents, however, have been living in their areas for a long time before strangers started to visit them. Thus, they have had to experience consistent changes in their own lives under protean tourism-related situations. Moreover, residents will continue living in their areas whether or not tourism development succeeds. In other words, only the residents will remain, regardless of the conditions of the destination. Thus, it seems an awkward question to ask how we can recognize those living at a tourist destination.

The narrow research topics employed to clarify the relevant causal relationships treat residents as just a part of a thriving tourism development process. In recent decades, many studies on residents in tourist destinations have been based on sustainability [2-5]. Two logical concepts can explain the importance of residents from the perspective of tourist destination sustainability. Once a tourist destination has been developed, it must be followed by tourist visits and consumption, so tourists' perceptions of the residents are as important as those of other tourist resources. These perspectives are important because residents' attitudes affect the tourists' visiting (revisiting) intentions [6]. Meanwhile, residents should be supportive of tourism development to sustain their places of residence and destination attractions. The economic profit and sociocultural advantages from the tourism industry could help encourage residents to support tourism $[4,7,8]$. However, focusing on the specific role of 
residents in satisfying tourists or on the specific factors needed to support residents is not enough, given that the primary reason for tourism development is the residents.

Further, modern influential methodologies sometimes regard residents' lives as schematized data for two reasons. The first is that a positivist approach to resident research reveals hidden situations using verified variables and manipulative definitions because quantitative methods refine and investigate factors that are already known. However, sufficiently diverse variables do not exist to thoroughly explain how residents perceive tourism [9-11]. The other reason is that the cross-sectional approach of resident research makes ongoing conditions seem to be temporary incidents, by focusing on limited timeframes like festival periods [9,12-14]. It is thus reasonable to apply a qualitative approach to identify why some of the hypotheses of past resident research remain unverified [15].

Residents must become a significant theme in tourism studies more than any topic, not through an apparent cause-and-effect relationship, but through their own integrated daily lives $[9,16]$. In developing this comprehensive view, the present paper captures the essence of residents' experiences in tourist destinations. That is, by inspecting residents' specific situations with highly subjective complexity, this study analyzes the current existence of residents without proving particular objective facts. For this reason, this paper does consider residents as an attractive resource for the interconnection between destinations and tourists, as an opponent to be persuaded for tourism development, or as a seeker to be gained through tourism engagement. Therefore, this paper adopts an interpretive approach, a longitudinal question, and an individual case-oriented interview. In this way, we established two research questions: Q1) Is it possible to improve our understanding of residents in a tourist destination without proving variable relationships? Q2) Is it possible to improve our understanding of the residents in a tourist destination by studying longitudinal experience?

\section{Literature Review}

When tourism development occurs, the lives of the area's residents change in many ways. Nevertheless, these residents must accept such changes and continue their lives; the feelings of this process may be both hopeful and hopeless. If the future of tourism is considered hopeful, residents will interpret tourism development favorably, but if it is considered inconvenient and unavoidable, they may perceive such development as hostile, which will lead to either positive or negative support for tourism development. The SET (Social Exchange Theory) [17] has been used to explain that residents are supportive of tourism development when the benefits of tourism outweigh the losses. [15,18,19]. SET is "a general sociological theory concerned with understanding the exchange of resources between individuals and groups in an interaction situation" [20]. Furthermore, prior studies have studied what factors make residents react positively nor negatively toward tourism development using SET [9]. The regional economic effects from the tourism industry result in more significant employment opportunities and higher wages [21]; on the other hand, revitalizing the local economy leads to higher taxes, soaring real estate prices, and increased living costs [15]. Such research on the phenomena of individuals as residents and the situation of tourism has usually been undertaken to reveal the factors underlying support for tourism development.

Under tourism, an area where residents have lived for a long time becomes well-known, and the onset of visits by outsiders also changes the lives of residents. Tourists are strangers to the residents and stay for only a short period. Nevertheless, with repeated and intermittent encounters with various targets, residents become accustomed to their relationship with tourists. A large number of tourists visiting an area strengthens the pride of the residents because it means that their destination is superior [22]. Thus, due to the interest of tourists, residents may preserve the valuable natural environment and traditional culture in the destination [21]. On the other hand, growing pressure on tourists has made residents think negatively about tourists [23,24]. Residents' negative attitudes toward tourists are a result of exceeding the area's human capacity limit. In particular, the crime, trash, and traffic congestion caused by the actions of tourists have adverse social and cultural impacts on residents $[25,26]$. Recently, research has been conducted on tourism development that exceeds the 
capacity of the destination using overtourism and gentrification theories [22]. Previous studies have shown that the relationship between residents and tourists is sometimes understood as an interaction between hosts and guests, and SET has been applied to study the balance between these parties [18,27]. As a result, studies show that when the expected benefits set by tourists and perceived by residents are balanced, their interactions proceed without conflict [28]. However, few studies have examined the socio-psychological situations resulting from the establishment of a relationship between the people who maintain the destination and the people who visit the destination for a short period.

After tourism development, the community atmosphere in the region is also different from when most residents were engaged in agriculture or manufacturing. Unlike traditional industries, tourism generates profits at the same time as supply, so there are antithetical relative conditions to cooperation or competition among the residents. Reasonably, the community can collectively express its position on tourism development to pursue collective interests and, in this way, enhance the positive effects of tourism. In order to maximize the economic, social, and cultural benefits, it is better to communicate with the community and to redistribute profits than to engage in individual actions [29,30]. However, these findings seek profit from the perspective of residents, but fail to explain the different positions and related changes made by tourism interests within the community [28,31]. Few studies show the individual positions of residents. Previous studies assume the homogeneity and unidirectionality of the community, despite the presence of heterogeneity among residents [20,32,33]. Thus, various attitudes toward tourism within the community should be analyzed in future work [33].

Based on the theoretical review above, to gain a deeper understanding of the lives of residents in a tourist destination, it is necessary to examine the following three elements of previous tourism studies that discussed residents.

1. Studies about the stance of the individual as a resident in the tourist destination on tourism development

2. Studies on the influence of the interaction between individuals as residents and tourists

3. Studies on the relationship emerging from the situation of tourism within the local community

However, when considering the above three areas, using the existing theories of fragmented frames is insufficient. Therefore, because more extensive and integrated research is needed [34], the precedence of macroscopic investigations without structural research suppositions could inspire further studies. The present study adopted a phenomenological research methodology to perform empirical tests suggested by the many past studies on residents $[9,16]$.

\section{Methodology}

\subsection{The Phenomenological Approach}

An interpretive approach regards humans as autonomous organizational units with motivations, values, and consciousness, and also regards humans' daily lives as a process of constantly acting and interacting within social circumstances [35]. Phenomenology is a typical qualitative research method that has become influential in the 20th century. Using this method, researchers study humans via the complex characteristics of perception and judgement, as participants describe their personal subjective experiences or phenomena [36]. Thus, because a phenomenological approach analyzes profound and personal experiences [37,38], the residents' experiences can be understood subjectively. This method, then, corresponds with the purpose of this paper: To determine the essence of living in a tourist destination. This phenomenological approach started with "a phenomenology of tourism experience" [39] and can be applied to tourism studies because the focus of a tourism study is to understand human experience [40]. Tourists' subjective values (not just for sight-seeing) have been explored [41,42], and various interrelational roles, such as tourists, guests, residents, hosts, service providers, and other stakeholders, have been interpreted [43]. In addition, many types of research 
have emphasized the importance of understanding personal experiences using an empirical paradigm in tourism studies [44-47].

The phenomenological approach is based on Husserl's philosophy. To describe the universal essence of personal experiences, researchers should collect resources from people who have experienced the same phenomenon and then describe the complex factors underlying the experiences of all individuals. The phenomenological framework has three consecutive stages: Phenomenological reduction, description, and establishing essence $[48,49]$. This study performed phenomenological reduction and description via a content analysis, which consisted of coding the data, finding the themes, editing the codes and themes, and defining the findings [50]. Lastly, the structure of the phenomenon is expressed to accurately search for the essence of the studied theme.

\subsection{The Study Site}

Three conditions were considered when determining the study site. The site had to be a world-famous Korean tourist destination, had to have long-term residents who agreed to longitudinal interviews, and had to have undergone many socio-cultural changes over several decades. The Bulguksa area in Gyeongju was selected because it met all the criteria. Moreover, this study assumes that the tourism policies of an area are connected to all other activities in that area [51]. Accordingly, the historical, spatial, and geographical characteristics of the destination must be explained. Bulguksa, built in the 6th century, became a UNESCO World Cultural Heritage site in 2000 [52]. This $40 \mathrm{~km}^{2}$ region, which has been called Bulguk-dong, consists of eight administrative districts: Jinhyeon-dong, Ma-dong, Ha-dong, Pyeong-dong, Sirae-dong, Gujeong-dong, Joyang-dong, Si-dong, and 30 villages [53]. Shilla Dynasty tourist attractions are present in the center of Gyeongju, including Anabji, Cheonmachong, and Cheomseongdae. Bulguk-dong is also an important Buddhist heritage site with 40 cultural assets. This heritage site, however, is a farming area $20 \mathrm{~km}$ away from the city center's tourist destinations.

There have been many alterations in the industrial tourism conditions at Bulguk-dong. During the Second World War, this place became well-known as a tourist destination due to having railroads. For example, Gyeongju became popular for school field trips and honeymoons. Houses and rice paddies, along with the old temple site, offered lodging and dining services. In 1962 and 1972, demolitions created a commercial district in Bulguksa. The Bulguksa purification project (1972 to 1975) was part of the Comprehensive Development of the Gyeongju Tourism Project. The houses around the temple were demolished and replaced with hotels, inns, parking lots, and parks [54]. Presently, accommodations exist for groups of more than 100 tourists. There are also many souvenir stores, restaurants, and other related accommodations. The local residents still live in traditional farmhouses around the commercial areas, as they have done for generations. Some of them work directly in the Bulguksa commercial district, while others are affected more indirectly by the profits from the Bulguksa commercial district.

\subsection{Participants and Data Collection}

The study participants were chosen to provide the best information about the research subject $[9,55]$. All of the study participants live in Bulguk-dong and represent a wide range of occupations. The participants were categorized as 1) residents in direct contact with tourists by working at tourism businesses; 2) residents in contact with tourists at their own businesses; 3 ) residents in regular contact with tourists but only deriving part of their income from tourism; and 4) residents having no contact with tourists. The participants were evenly distributed by age and gender. We examined people in their 70s to 80 s who remembered when the village's accommodations were formed, as well as those in their 30 s to 40 s who belong to a generation of school excursion travelers.

Because sufficient information was needed to generate the research data, researchers visited and observed the destination twice and interviewed 13 participants in-depth. The researchers stayed in the destination for five days during the first participation observation, explained the purpose of the research, and formed a report while visiting communities, such as the local autonomous community, the elderly association, and the farmers' association. On the third day, we attempted to meet one-on-one 
to comfortably exchange our views on tourism development. After the first voluntary interview participant, the following participants were introduced through the effective method of Snowball Sampling for organic social network research [56]. A total of eight interviews were conducted by selecting the interviewees based on a uniform distribution of the aforementioned categories and ages among the applicants. Researchers stayed in the destination for four days through the second round of observers, meeting with the interviewers again and re-interviewing participants who wanted to testify further. In addition, five new participants were interviewed. From the beginning, the number of participants in the survey was not limited, but we decided to stop the interview process as similar data were accumulated after five additional in-depth interviews. Table 1 presents the study participants.

Table 1. The participants.

\begin{tabular}{|c|c|c|c|}
\hline ID & Age & Gender & Occupation Condition \\
\hline Participant 1 & $70 \mathrm{~s}$ & M & direct contact with tourists by working in tourism businesses \\
\hline Participant 2 & $50 \mathrm{~s}$ & M & direct contact with tourists by working in tourism businesses \\
\hline Participant 3 & $70 \mathrm{~s}$ & $\mathrm{~F}$ & regular contact with tourists, but only deriving part of their income from tourism \\
\hline Participant 4 & $80 \mathrm{~s}$ & $\mathrm{~F}$ & regular contact with tourists, but only deriving part of their income from tourism \\
\hline Participant 5 & $60 \mathrm{~s}$ & M & residents having no contact with tourists \\
\hline Participant 6 & $30 \mathrm{~s}$ & M & contact with tourists at their own businesses \\
\hline Participant 7 & $30 \mathrm{~s}$ & M & residents having no contact with tourists \\
\hline Participant 8 & $40 \mathrm{~s}$ & M & contact with tourists at their own businesses \\
\hline Participant 9 & $70 \mathrm{~s}$ & M & residents having no contact with tourists \\
\hline Participant 10 & $50 \mathrm{~s}$ & M & regular contact with tourists, but only deriving part of their income from tourism \\
\hline Participant 11 & $30 \mathrm{~s}$ & $\mathrm{~F}$ & regular contact with tourists, but only deriving part of their income from tourism \\
\hline Participant 12 & $50 \mathrm{~s}$ & M & regular contact with tourists, but only deriving part of their income from tourism \\
\hline Participant 13 & $60 \mathrm{~s}$ & $\mathrm{~F}$ & contact with tourists at their own businesses \\
\hline
\end{tabular}

The interview was followed by a semi-structured interview after explaining the in-depth interview methods and the rights of the participants. The interview questions consisted of how the participants lived in tourist destinations, the events they experienced in their lives, changes in their careers, local relationships, and demographic data, including their ages, livelihoods, and family relationships.

\section{Findings}

The results are presented through three themes and five sub-themes based on the three categories analyzed in the literature review (Table 2).

Table 2. Results of the thematic analysis.

\begin{tabular}{cc}
\hline Themes & Sub-Themes \\
\hline \multirow{2}{*}{$\begin{array}{c}\text { Being a resident with } \\
\text { an inevitable choice }\end{array}$} & A fatalistic attitude \\
\cline { 2 - 2 } $\begin{array}{c}\text { The meaning of tourism in the } \\
\text { lived experience as a resident }\end{array}$ & Focal patriotism \\
\cline { 2 - 2 } & Planning the future by considering a family business founded in tourism \\
\hline Formation of conflicts & Different positions based on the local tourism industry's conditions \\
\hline
\end{tabular}

\subsection{Theme 1: Being a Resident with an Inevitable Choice}

The most important finding of this study was that the connection between the residents and tourism is an inevitable choice. The most commonly explainable result from these interviewees is that the motives behind being a resident in a tourist destination were their objective situations that produced inevitable conditions. That is, their acceptance of tourism as a crucial part of life cannot be regarded as a result of their ideal choice, even though their motives were different according to their circumstances. 


\subsubsection{Sub-theme 1: A Fatalistic Attitude}

"I live here just because I was born here." (Participant 5)

This simple answer from a person born in the village shows a fatalistic attitude. Participant 3 was born in a poor household in a neighboring village and had an arranged marriage to a man living near Bulguksa.

"I just accepted the situation that the people whom I live with were changed, from my parents to my husband, and everything was the same. The big temple here did not matter. I just live in a poor farmhouse. It did not matter whether there was a big temple or a big church or not." (Participant 3)

Participant 3 became a resident by marriage, and she accepted her life in the tourist destination because she did not seem to care if such a life were good or bad.

Participant 2 made money outside of Bulguk-dong to expand his lodging business. He inherited his family business. When asked if it was different to move to another city or to learn skills to have a different job, he answered:

"My family is very patriarchal. My parents started a business for tourists here after quitting farming, and because of this situation requiring my hands, I've never thought of having my own life apart from my family." (Participant 2)

\subsubsection{Sub-theme 2: Local Patriotism}

Participant 1 could have acquired a job after finishing his studies elsewhere, but he chose to live in his hometown. This might be local patriotism. However, his true psychological path is revealed through his memory of one incident.

"When I was young and looking for a job, there was a tremendous change in my hometown. Because the area became well-known, private investors, as well as public institutes, were involved along with secret and illegal interests. I couldn't bear the situation. I just wanted to farm as we used to. I didn't have any desire to make money from tourism. I didn't have trouble with people outside of the community. However, when I tried to build a waterway for my farm, there were many obstacles. Because many interests were involved, the rules were changed as the people with the power wanted. That's why I wanted to keep my hometown." (Participant 1)

Meanwhile, Participants 7 and 8 became community members out of homesickness. They went to college or obtained jobs in big cities, but then came back to their hometown. They experienced psychological conflicts until they decided to live in this area again. They also felt lonely or alienated too often when they lived with people of different cultures.

\subsection{Theme 2: The meaning of Tourism in the Lived Experience as a Resident}

Because tourists come and go, the residents of tourist destinations feel like they live with strangers. This study found that children and adolescents are the most strongly affected by tourists.

\subsubsection{Sub-theme 3: Formation of the Inner Self with Tourists' Influences}

Relationships with tourists affected the residents' internal formation. A partial result of this phenomenon is the avoidance of guilt. When participants were asked about their experiences when young, they described taking money from the donation box in the temple, buying liquor, and lying about their age.

"Since I was sure that I wouldn't see them (the tourists) again, I could do what I otherwise couldn't do." (Participant 6) 
"When the store owner left the store for a moment, the tourist mistook me as the son of the owner. Then I charged 1,200 won for a 1,100 won (KRW) item. I didn't mean to, but I felt guilty when I found out that I charged more, but soon, I thought that it's ok because I really didn't mean to. I also thought that I wouldn't see him again, and he wouldn't remember me. Actually, I felt comfort thinking that he's the one whom I would never see, so it would be over when this moment was gone." (Participant 5)

In addition, during processes in which identity and personal pride were established, the relationships with tourists functioned well. Comparing themselves with tourists of the same age and gender sometimes increased the self-esteem of residents:

"I envied girls from Seoul who had round bangs. I went to the inn to help my mom and saw girls in that style listening to music. I was jealous and felt humble, but I also felt the opposite. This week, some students wore skinny jeans for fashion, and the next week, other students wore baggy pants for fashion. Because this fashion was not consistent, I thought they looked funny and ridiculous, rather than wanting to follow the fashion. Of course, the clothes they wore looked expensive, but we felt proud since we only use domestic items instead of me begging my parents to buy the same ones." (Participant 11)

\subsubsection{Sub-theme 4: Planning the Future Considering a Family Business Founded in Tourism}

Tourism affects residents' decisions about their future. The fact that residents live in a tourist destination has a large influence on young people's careers. Many participants grew up planning to work for hotels, restaurants, and tourism businesses. Families are also affected by the decisions of the young generations. However, the results show that a tourism business cannot be assured to exert only a positive influence or a negative influence, even if it creates many job opportunities, including in the service industry.

"It sounds like an excuse, but I wasn't that good in school, and I didn't think that I would be successful as a white-collar worker, so I didn't take going to college seriously since I was young. It might have been different if I saw the old people here who just farmed, but I saw many tourists coming and buying food here. I thought that I could make money fast if I opened a small restaurant. Then, I could get married and take care of my parents. Those kinds of things were important to me." (Participant 4)

"My son was always interested in technology and sought his aptitude by comparing it with his friends'. He says that wants to leave this city to find a career in technology. Gyeongju does not have factories or big companies, and there is no possibility of having such things because it is a tourism city. That's why I have always prepared for my son's independence. I have also prepared mentally and financially for my life when I am old and alone." (Participant 12)

Participant 9 is in a unique situation because his house is on a street that has a small cultural asset. Therefore, he is not allowed to build in the area, and he cannot sell it to a person with a commercial purpose. He is struggling to support his children and does not know where he will live in his later years.

\subsection{Theme 3: Formation of Conflicts}

The final outcome of this study analyzes conflict. The relationship between tourism and resident occupations can cause conflicts between residents.

Sub-theme 5: Different Positions Based on the Local Tourism Industry's Conditions

Gyeongju City has been registered as a World Cultural Heritage by the UNESCO [52] and has hosted the World Culture Expo 11 times [53]. Lodging and other tourism businesses that are run by outsiders are different from those run by natives. 
"A lodging business like a $B \mathcal{E} B$ is a concept in which residents engage in conventional farming, providing food and accommodation on a small scale in the conventional form of houses during the agricultural-break season. However, those which have sprouted up in Gyeongju are different. They have been newly built in the European or American style, according to the most up-to-date fashion. Thus, I feel very sorry that there are such accommodations in Gyeongju, a tourist destination for traditional culture." (Participant 1)

Participant 1 emphatically denied that his situation has anything to do with profit, but he feels infuriated only at the transformation of the regional image of Gyeongju (because the new visitors are different from his customers). Residents' desire to protect the peculiarities of their local area can cause conflict with new residents. Participant 2 feels that it is important to consider the distribution of profits.

"Those who have property or families in other areas do not consume the money they earn here but send it outside. Previously, as the tourists from other areas gathered and those engaged in lodging businesses made some money, our towns became rich. However, this is not the case now. I always feel very it is very unfair that the situation is unequal." (Participant 2)

In other words, residents should share their profits with people from other areas, but Participant 2 is fond of the area.

Also, there are times when the residents recognize that the business related to the problem of profit involves a clear difference of position. The participants who run accommodations resent the construction of large hotels. However, the participants engaged in the logistics of restaurants believe that a larger number of accommodations will help develop tourism. Those who make their living from businesses other than tourism do not seem to have strong feelings either way.

"The trend naturally flows in and out. We can see this or that kind of happening. At present, lodging businesses run by people from other areas are in fashion. I believe that the government feels that this is now required in Gyeongju." (Participant 10 )

"Everything has its ups and downs. Even though the lodging business in our town has been very prosperous, it cannot be guaranteed to maintain the same trend." (Participant 13)

4.4. The Structure of the Phenomenon: A Route for Individuals to Protect Themselves within an Ever-changing Social Structure

The final result of this study is an integrated explanation of the essence of the residents' lives. When the experience of living as a resident in a tourist destination is approached phenomenologically, it becomes a route for individuals to protect themselves within an ever-changing social structure. Because several values and relationships are involved between certain experiences and choices, it is difficult to assure that all people will live most beneficially. However, people make decisions using their 'identity' to determine the appropriateness of their direction at every moment.

\section{Discussion}

By assuming that the lives of residents are difficult to schematize, this study has attempted to conduct phenomenological research in which the essence of lived experience is understood via the subjective recognition of an individual. From the outcomes thus derived, three factors for discussion can be put forth.

The first finding for being a resident with an inevitable choice indicates that the residents do not make a rational choice for the greatest gain; however, they do accept a situation based on their values. This is connected to the previous studies that proved the impacts of tourism development cannot explain each resident's unique way of thinking [11]. Because each individual has different values, each local resident takes a different stance on their involvement in and support for tourism development. For this reason, there is still a need to study the multivariate values of local residents, 
despite a great deal of research [57-59] on the socio-cultural effects of tourism. Future research should assume that local residents' attitudes toward tourism can be determined by their own internal factors (values), not by the resultant factors in tourism development. Tourism studies can provide more meaningful information to tourism policymakers by identifying the values (fatalistic attitudes and local patriotism in this study) related to residents' attitudes toward tourism, and by verifying their influence on local residents' behavioral choices. For example, by analyzing residents' inclinations in a destination ahead of tourism development on the basis of these factors, it is possible to suggest which policies would be more contributive to the destination, whether they be guaranteed employment at large externally-invested hotels or supported by the direct operations of small accommodations.

The second finding of the meaning of tourism via the lived experience of a resident indicates that the tourism industry has long-term lasting effects on the local residents in the destination. Social Exchange Theory has often been used for studies on residents [20], but the 'expected benefit balance' and 'exchange' are valid only for a short timeframe. In reality, the balance-point of the residents continues to fluctuate, whereas tourist visits persist. However, if the balance of expected benefits is broken, and exchange does not happen, the problems of the residents do not stop there. Residents continue living in the area, regardless of whether this exchange status lasts, under the conditions that have been changed by the expectations of residents (for example, an extended room in anticipation of an increased number of guests or a family member who quit his or her previous job for a home-based tour program). Thus, cross-sectional research should be increased to develop responsible logic for the 'continuous lives after the events' of residents in the tourist destination.

The last finding of the Formation of conflict indicates that the internal and external conflicts of the residents arise from the same thing. Considering that conflicts arise due to the differences in residents' positions on the same incident, tourism studies should further examine the conflicts of the residents. In recent decades, sociology has interpreted conflicts from a traditional perspective and a cognitive perspective. The traditional approach is an economic and exchangeable approach that understands conflict through material rewards. Therefore, it is understood that conflict control is a process in which participants adjust their mutual interests and reach an optimal point of benefit. On the other hand, the cognitive approach defines a cognitive frame about conflict issues as a conflict frame and asserts that the parties in a conflict will hold on to a specific mode of understanding and interpretation through the specific cognitive frame for the issues of conflict [60]. There is always complicated conflict between the various participants and issues of tourist destination. In particular, tourism studies should analyze the conflict frame structure and content perceived by residents and interpret the differences in the understanding of each position. Based on comprehensive conflict analysis modeling, it is possible to mutually communicate with residents in a tourist destination.

\section{Conclusions}

A municipality plans tourism development because tourism may be profitable for the residents in an area where traditional industries have collapsed [8,34]. Ironically, tourism studies sometimes analyze residents in order to successfully lead tourism development. By visualizing residents as they actually are, this study suggests that each resident is important as an individual. Like analyzing consumer behavior, the residents in a tourist destination need to be segmented by different conditions.

As the research questions of this study were explored, the theoretical implications were revealed. The first research question sought to improve our understanding of the residents in a tourist destination without proving variable relationships, and the second research question sought to improve our understanding of the residents in a tourist destination by gaining longitudinal experience. These results were confirmed by the effects of local patriotism. Many prior studies have demonstrated the psychological factors possessed by residents for positively supporting tourism development [61,62], but the psychological factors of residents were not the emotions that emerged when supporting tourism development in this study. Local patriotism allows residents to continue living at their destination under any circumstances, both in support of tourism development and in opposition to it. In addition, 
only conditions at a single time-point were explained by past studies that investigated residents' perceptions of tourist impacts. Intermittently meeting with tourists could affect the character formation of residents according to the longitudinal question. The residents' positions on tourists are subjective and difficult to measure [22], and a valid theory is needed to better understand the perceptions of tourists [63]. This study, prior to using a theoretical approach, observed, understood, and expanded the foundation of the views of the relationships that are formed among residents.

The influence of SET continues to be maintained, despite criticism that the theory cannot fully explain the perceptions of residents $[9,16,64]$. This is because researchers are too mindful of the relationship between the gains and losses of residents when explaining their experiences. It is necessary to look at the situation in an integrated way, away from the premise that exchanges occur. In this study, which looked at life as a resident, tourism development at the destination was a long-term process, not a single exchange. Thus, subsequent studies aimed at sustainability require discussions on the factors that can offer residents benefits and satisfaction over a long period. To do this, longitudinal studies are required, and comparisons with cross-sectional studies would also enrich the discussion. If we clarify the economic and social factors that cause changes in the tourist support and attitudes of residents over a long period of time, tourism research could consistently yield practical implications that are beneficial to the residents. This interpretative and exploratory research is expected to be used to provide new directions for future positivist research.

Author Contributions: Conceptualization, J.-E.L. and H.R.L.; methodology, J.-E.L.; investigation, J.-E.L.; writing—original draft preparation, J.-E.L.; writing—review and editing, H.R.L.; visualization, J.-E.L.; supervision, H.R.L. All authors have read and agreed to the published version of the manuscript.

Funding: This research received no external funding.

Conflicts of Interest: The authors declare no conflict of interest.

\section{References}

1. Budhiasa, I.G.S.; Riana, I.G. Managing Local Community Participation to Foster Sustainable Tourism Development, the Case of Bali Destination, Indonesia. J. Eng. Appl. Sci. 2019, 15, 291-298.

2. Choi, H.-S.C.; Sirakaya, E. Measuring Residents' Attitude toward Sustainable Tourism: Development of Sustainable Tourism Attitude Scale. J. Travel Res. 2005, 43, 380-394. [CrossRef]

3. Diedrich, A.; García-Buades, E.; García-Buades, M.E. Local perceptions of tourism as indicators of destination decline. Tour. Manag. 2009, 30, 512-521. [CrossRef]

4. Li, R.; Peng, L.; Deng, W. Resident Perceptions toward Tourism Development at a Large Scale. Sustain. 2019, 11, 5074. [CrossRef]

5. Yu, C.P.; Chancellor, H.C.; Cole, S.T. Measuring Residents' Attitudes toward Sustainable Tourism: A Reexamination of the Sustainable Tourism Attitude Scale. J. Travel Res. 2011, 50, 57-63. [CrossRef]

6. Sheldon, P.J.; Var, T. Resident attitudes to tourism in North Wales. Tour. Manag. 1984, 5, 40-47. [CrossRef]

7. Látková, P.; Vogt, C.A. Residents' Attitudes toward Existing and Future Tourism Development in Rural Communities. J. Travel Res. 2012, 51, 50-67. [CrossRef]

8. Kuvan, Y.; Akan, P. Residents' attitudes toward general and forest-related impacts of tourism: The case of Belek, Antalya. Tour. Manag. 2005, 26, 691-706. [CrossRef]

9. Sharpley, R. Host perceptions of tourism: A review of the research. Tour. Manag. 2014, 42, 37-49. [CrossRef]

10. Deery, M.; Jago, L.; Fredline, L. Rethinking social impacts of tourism research: A new research agenda. Tour. Manag. 2012, 33, 64-73. [CrossRef]

11. Harrill, R. Residents' Attitudes toward Tourism Development: A Literature Review with Implications for Tourism Planning. J. Plan. Lit. 2004, 18, 251-266. [CrossRef]

12. Hsu, C. Residents' Support for Legalized Gaming and Perceived Impacts of Riverboat Casinos: Changes in Five Years. J. Travel Res. 2000, 38, 390-395. [CrossRef]

13. Huh, C.; Vogt, C.A. Changes in Residents' Attitudes toward Tourism over Time: A Cohort Analytical Approach. J. Travel Res. 2008, 46, 446-455. [CrossRef] 
14. Ruspini, E. Longitudinal Research and the Analysis of Social Change. Qual. Quant. 1999, 33, $219-227$. [CrossRef]

15. Andrade, A.D. Interpretive Research Aiming at Theory Building: Adopting and Adapting the Case Study Design. Qual. 2007 Qual. Res. From Margins to Mainstream 2007, 14, 42-60.

16. Gannon, M.; Rasoolimanesh, S.M.; Taheri, B. Assessing the Mediating Role of Residents' Perceptions toward Tourism Development. J. Travel Res. 2020. [CrossRef]

17. Emerson, R.M. Social Exchange Theory. Annu. Rev. Sociol. 1976, 2, 335-362. [CrossRef]

18. Jurowski, C.; Uysal, M.; Williams, D.R. A Theoretical Analysis of Host Community Resident Reactions to Tourism. J. Travel Res. 1997, 36, 3-11. [CrossRef]

19. Nunkoo, R.; Smith, S.L.J.; Ramkissoon, H. Residents' attitudes to tourism: A longitudinal study of 140 articles from 1984 to 2010. J. Sustain. Tour. 2013, 21, 5-25. [CrossRef]

20. Ap, J. Residents' perceptions on tourism impacts. Ann. Tour. Res. 1992, 19, 665-690. [CrossRef]

21. Rasoolimanesh, S.M.; Jaafar, M.; Ahmad, A.G.; Barghi, R. Community participation in World Heritage Site conservation and tourism development. Tour. Manag. 2017, 58, 142-153. [CrossRef]

22. Szromek, A.; Kruczek, Z.; Walas, B. The Attitude of Tourist Destination Residents towards the Effects of Overtourism-Kraków Case Study. Sustain. 2019, 12, 228. [CrossRef]

23. Chen, N.; Hsu, C.; Li, X. (Robert) Feeling superior or deprived? Attitudes and underlying mentalities of residents towards Mainland Chinese tourists. Tour. Manag. 2018, 66, 94-107. [CrossRef]

24. MacKenzie, N.; Gannon, M.J. Exploring the antecedents of sustainable tourism development. Int. J. Contemp. Hosp. Manag. 2019. [CrossRef]

25. Akama, J.S.; Kieti, D. Tourism and Socio-economic Development in Developing Countries: A Case Study of Mombasa Resort in Kenya. J. Sustain. Tour. 2007, 15, 735-748. [CrossRef]

26. Jaafar, M.; Rasoolimanesh, S.M.; Ismail, S. Perceived Sociocultural Impacts of Tourism and Community Participation: A Case Study of Langkawi Island. Tour. Hosp. Res. 2017, 17, 123-134. [CrossRef]

27. Thompson, J.; Baxter, I.; Curran, R.; Gannon, M.; Lochrie, S.; Taheri, B.; Yalinay, O. Negotiation, bargaining, and discounts: Generating WoM and local tourism development at the Tabriz bazaar, Iran. Curr. Issues Tour. 2017, 21, 1207-1214. [CrossRef]

28. Bimonte, S.; Punzo, L. Tourist development and host-guest interaction: An economic exchange theory. Ann. Tour. Res. 2016, 58, 128-139. [CrossRef]

29. Jamal, T.; Getz, D. Collaboration theory and community tourism planning. Ann. Tour. Res. 1995, 22, $186-204$. [CrossRef]

30. Lee, T.H. Influence analysis of community resident support for sustainable tourism development. Tour. Manag. 2013, 34, 37-46. [CrossRef]

31. Zhang, J.; Inbakaran, R.J.; Jackson, M.S. Understanding Community Attitudes Towards Tourism and Host-Guest Interaction in the Urban-Rural Border Region. Tour. Geogr. 2006, 8, 182-204. [CrossRef]

32. Ap, J.; Crompton, J.L. Residents' Strategies for Responding to Tourism Impacts. J. Travel Res. 1993, 32, 47-50. [CrossRef]

33. Fredline, E.; Faulkner, B. Host Community Reactions: A Cluster Analysis. Ann. Tour. Res. 2000, $27,763-784$. [CrossRef]

34. Faulkner, B.; Tideswell, C. A Framework for Monitoring Community Impacts of Tourism. J. Sustain. Tour. 1997, 5, 3-28. [CrossRef]

35. Tuohy, D.; Cooney, A.; Dowling, M.; Murphy, K.; Sixsmith, J. An Overview of Interpretive Phenomenology as a Research Methodology. Nurse Res. 2013, 20, 17-20. [CrossRef]

36. Giorgi, A. The Theory, Practice, and Evaluation of the Phenomenological Method as a Qualitative Research Procedure. J. Phenomenol. Psychol. 1997, 28, 235-260. [CrossRef]

37. Chen, L.; Chen, T.-L.; Lin, C.-J.; Liu, H.-K. Preschool Teachers' Perception of the Application of Information Communication Technology (ICT) in Taiwan. Sustain. 2018, 11, 114. [CrossRef]

38. Brocki, J.M.; Wearden, A.J. A critical evaluation of the use of interpretative phenomenological analysis (IPA) in health psychology. Psychol. Heal. 2006, 21, 87-108. [CrossRef]

39. Cohen, E. A Phenomenology of Tourist Experiences. Sociology 1979, 13, 179-201. [CrossRef]

40. Casmir, F.L. Phenomenology and hermeneutics: Evolving approaches to the study of intercultural and international communication. Int. J. Intercult. Relations 1983, 7, 309-324. [CrossRef]

41. Andriotis, K. Sacred Site Experience. Phenomenol. Study. Ann. Tour. Res. 2009, 36, 64-84. [CrossRef] 
42. Malone, S.; McCabe, S.; Smith, A.P. The role of hedonism in ethical tourism. Ann. Tour. Res. 2014, 44, 241-254. [CrossRef]

43. Pernecky, T.; Jamal, T. (Hermeneutic) Phenomenology in tourism studies. Ann. Tour. Res. 2010, 37, 1055-1075. [CrossRef]

44. Masberg, B.A.; Silverman, L.H. Visitor Experiences at Heritage Sites: A Phenomenological Approach. J. Travel Res. 1996, 34, 20-25. [CrossRef]

45. Pons, P.O. Being-on-Holiday: Tourist Dwelling, Bodies and Place. Tour. Stud. 2003, 3, 47-66. [CrossRef]

46. Uriely, N.; Belhassen, Y. Drugs and Tourists' Experiences. J. Travel Res. 2005, 43, 238-246. [CrossRef]

47. Willson, G.; McIntosh, A.; Zahra, A. TOURISM AND SPIRITUALITY: A PHENOMENOLOGICAL ANALYSIS. Ann. Tour. Res. 2013, 42, 150-168. [CrossRef]

48. Giorgi, A. The Descriptive Phenomenological Psychological Method. J. Phenomenol. Psychol. 2016, 43, 3-12. [CrossRef]

49. Groenewald, T. A Phenomenological Research Design Illustrated. Int. J. Qual. Methods 2004, 3, 42-55. [CrossRef]

50. Türkoğlu, B. Opinions of Preschool Teachers and Pre-Service Teachers on Environmental Education and Environmental Awareness for Sustainable Development in the Preschool Period. Sustain. 2019, 11, 4925. [CrossRef]

51. McKercher, B. Some fundamental truths about tourism: Understanding tourism's social and environmental impacts. J. Sustain. Tour. 1993, 1, 6-16. [CrossRef]

52. UNESCO. World Heritage List. Gyeongju Historic Areas. Available online: http://whc.unesco.org/en/list/976/ (accessed on 9 December 2019).

53. Gyeongju City. Administrative Region Information. Available online: http://www.gyeongju.go.kr/open_ content/ko/page.do?mnu_uid=286\& (accessed on 9 December 2019).

54. Kang, S.; Kim, J.; Nicholls, S. National Tourism Policy and Spatial Patterns of Domestic Tourism in South Korea. J. Travel Res. 2014, 53, 791-804. [CrossRef]

55. Forsey, M. Ethnography as participant listening. Ethnography 2010, 11, 558-572. [CrossRef]

56. Noy, C. Sampling Knowledge: The Hermeneutics of Snowball Sampling in Qualitative Research. Int. J. Soc. Res. Methodol. 2008, 11, 327-344. [CrossRef]

57. Li, M.; Cai, L.A. The Effects of Personal Values on Travel Motivation and Behavioral Intention. J. Travel Res. 2012, 51, 473-487. [CrossRef]

58. O'Riordan, T.; Mathieson, A.; Wall, G. Tourism: Economic, Physical and Social Impacts. Geogr. J. 1983, 149, 371. [CrossRef]

59. United, N. E. S. A.; Cultural Organization (UNESCO). The Effects of Tourism on Socio-Cultural Values. Ann. Tour. Res. 1976, 4, 74-105. [CrossRef]

60. Hahn, T.; Preuss, L.; Pinkse, J.; Figge, F. Cognitive Frames in Corporate Sustainability: Managerial Sensemaking with Paradoxical and Business Case Frames. Acad. Manag. Rev. 2014, 39, 463-487. [CrossRef]

61. Choi, H.C.; Murray, I. Resident attitudes toward sustainable community tourism. J. Sustain. Tour. 2010, 18, 575-594. [CrossRef]

62. Williams, D.R.; Mcdonald, C.D.; Riden, C.M. Community Attachment, Regional Identity and Resident Attitudes Toward Tourism. Available online: https://www.fs.fed.us/rm/pubs_other/rmrs_1995_williams_ d001.pdf (accessed on 18 February 2020).

63. Moghavvemi, S.; Woosnam, K.M.; Paramanathan, T.; Bin Musa, G.; Hamzah, A. The effect of residents' personality, emotional solidarity, and community commitment on support for tourism development. Tour. Manag. 2017, 63, 242-254. [CrossRef]

64. Rasoolimanesh, S.M.; Jaafar, M.; Kock, N.; Ramayah, T. A revised framework of social exchange theory to investigate the factors influencing residents' perceptions. Tour. Manag. Perspect. 2015, 16, 335-345. [CrossRef]

(C) 2020 by the authors. Licensee MDPI, Basel, Switzerland. This article is an open access article distributed under the terms and conditions of the Creative Commons Attribution (CC BY) license (http://creativecommons.org/licenses/by/4.0/). 